\title{
Microbial Activity as Influenced by Sunflower Residue Incorporation, Method of Establishment and Nutrient Management of Rice in Rice- Greengram Sunflower Cropping System in Odisha, India
}

\author{
Tapas Ranjan Sahoo $^{1 *}$, R. K. Paikaray ${ }^{1}$, K. N. Mishra ${ }^{2}$ and B. S. Rath ${ }^{3}$ \\ ${ }^{1}$ Department of Agronomy, College of Agriculture, OUAT, Bhubaneswar, India \\ ${ }^{2}$ Department of Soil Science and Agril Chemistry, College of Agriculture, OUAT, India \\ ${ }^{3}$ Department of Agril Meteorology, College of Agriculture, OUAT, Bhubaneswar, India \\ *Corresponding author
}

\section{A B S T R A C T}

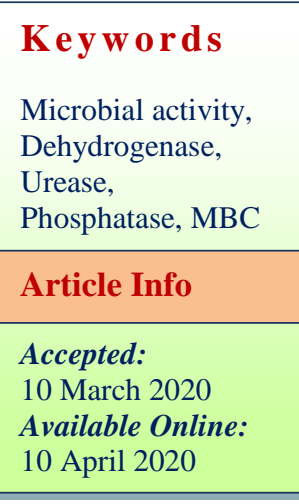

A field experiment was conducted at main research farm of OUAT, Bhubaneswar, Odisha. The experiment was laid out in double split design with 27 treatment combinations and three replications. In main plot sunflower residue was removed in one plot, incorporated in another plot and in third plot no sunflower was grown. In subplot three methods of establishment of rice was taken namely dry direct seeded, wet direct seeded and transplanting method of rice establishment. Three different nutrient management practices was given to rice in sub sub plot i.e. first is fully organic where only FYM was used as nutrient source, in second one integrated approach was followed through 75 percent of nitrogen through inorganic nutrient source with 25 percent of organic source and the third case is pure inorganic where only chemical fertilizer was given at the rate of $60-30-30 \mathrm{~kg}$ of $\mathrm{N}-\mathrm{P}_{2} \mathrm{O}_{5}-\mathrm{K}_{2} \mathrm{O}$ per ha. After harvest of rice, green gram crop was taken under residual soil moisture and soil nutrient status. Dehydrogenase activity, phosphatase activity, urease activity and total microbial biomass carbon were higher in sunflower residue incorporation and organic source of nutrient.

\section{Introduction}

Rice and rice based cropping systems are of prime importance for food security mainly in South and South East Asia. Rice and pulses are the major portion of the human diet. With growing concern about human health, soil quality and environmental safety, need has been felt to reevaluate over the existing agricultural practices viz. continuous monocropping which has led to decline or stagnation of productivity due to deterioration of soil physio-chemical properties. This problem can be partly overcome with more focus on agricultural practices such as green manuring, recycling of crop residues, and 
inclusion of legumes in rotation. The selection of component crops needs to be suitably planned to harvest the synergism among them towards efficient utilization of resource base and to increase overall productivity.

Crop sequencing can put emphasis on synergistic interactions among crops (Tanaka et al., 2005). Inclusion of legume in the cropping system definitely improves the soil physic chemical and biological properties.

Also incorporation of crop residue in the soil improves the soil organic carbon. Another aspect of crop residue management is its effect on the microbial community that regulates soil health. The microbes mineralize organic matter and release essential nutrients into the soil enabling the biogeochemical processes.

Despite well-known role of microbes in the soil, not much impetus has been laid to study their activity through different enzymatic activity under crop residue management.

Source of nutrient also has impact on microbial activity. As we know, organic source of nutrient has direct impact on the soil microbial activity as this acts as ready source of carbon for their growth and development. An attempt has been made to evaluate the effect of source of nutrients in rice on microbial activity in rice-sunflowergreengram system.

\section{Materials and Methods}

The experiment was conducted at main research farm of OUAT, Bhubaneswar, Odisha. The experiment was laid out in double split design with 27 treatment combinations and three replications. In main plot sunflower treatment was taken, in first plot sunflower was grown only, in second plot sunflower was grown along with incorporation of the sunflower residue and the third main plot was taken as control where no sunflower was grown. After sunflower rice was taken in the sub plot with three established methods as dry direct sowing, wet direct sowing and transplanted.

Three different nutrient management practices was given to rice in sub sub plot i.e. first is fully organic where only FYM was used as nutrient source, in second one integrated approach was followed through 75 percent of nitrogen through inorganic nutrient source with 25 percent of organic source and the third case is pure inorganic where only chemical fertilizer was given at the rate of 60$30-30 \mathrm{~kg}$ of $\mathrm{N}-\mathrm{P}_{2} \mathrm{O}_{5}-\mathrm{K}_{2} \mathrm{O}$ per ha.

After harvest of rice, green gram crop was taken under residual soil moisture and soil nutrient status. The variety used for rice was Naveen. The dehydrogenase activity in the soil samples was determined by following the procedure as described by Casida et al., (1964).

Phosphatase activity of soil samples was determined by following the procedure of Evazi and Tabatabai (1979). The procedure adopted to determine the urease activity of soil was essentially the same as adopted by Pancholy and Rice (1973) except that the ammonia liberated due to hydrolysis used in the reaction mixture was determined by nesslerization as described by Jackson (1973). The microbial biomass carbon (Cmic) was determined by chloroform fumigation extraction method as described by Vance et al., (1987).

\section{Results and Discussion}

The data on dehydrogenase activity ( $\mu \mathrm{g}$ TPF $\mathrm{g}^{-1}$ soil day $^{-1}$ ) as influenced by sunflower residue incorporation, method of establishment and source of nutrient has been 
presented in Table 1. During 2016-17, before growing sunflower crop, there was no significant difference in dehydrogenase activity in the bulk soil.

Before growing rice as well as greengram, dehydrogenase activity was significantly higher in the plot where sunflower residues were incorporated. Before greengram, the dehydrogenase activity was as high as 72.08 $\mu \mathrm{g}$ TPF $\mathrm{g} \mathrm{soil}^{-1}$ day $^{-1}$.

Among the methods of establishment, there has been no significant difference in dehydrogenase activity before different crops. But, numerically higher dehydrogenase activity was seen in case of dry direct sowing before all the crops.

There was significant difference in dehydrogenase activity among the various sources of nutrient. Organic source of nutrient resulted in highest dehydrogenase activity before all the crops in both the years followed by $75 \% \mathrm{RDF}+25 \%$ organic and RDF.

The interaction effect was found to be non signif.The data on acid phosphatase activity ( $\mu \mathrm{mol}$ paranitrophenol $\mathrm{g}$ soil $^{-1} \mathrm{hr}^{-1}$ ) as influenced by sunflower residue incorporation, method of establishment and source of nutrient before growing various crops has been presented in Table 2 .

Before growing sunflower crop, there was no significant difference in phosphatase activity in the bulk soil. Before growing rice as well as greengram, phosphatase activity was significantly higher in the plot where sunflower residues were incorporated. Before greengram, the phosphatase activity was 1.94 $\mu \mathrm{mol}$ paranitrophenol $\mathrm{g} \mathrm{soil}^{-1} \mathrm{hr}^{-1}$.

There has been no significant difference in phosphatase activity before different crops among the methods of establishment. But, numerically higher phosphatase activity was observed in wet direct sowing before all the crops.

There was no significant difference in phosphatase activity among the various sources of nutrient during 2016-17. The interaction effect was found to be non significant.

The results of the analysis on acid urease activity $\left(\mu \mathrm{g} \mathrm{NH}{ }^{+} \mathrm{g}\right.$ soil $\left.^{-1} \mathrm{hr}^{-1}\right)$ as influenced by sunflower residue incorporation, method of establishment and source of nutrient before growing various crops has been presented in Table 3.

Before growing sunflower crop in the first year, there was no significant difference in urease activity in the bulk soil. Before growing rice as well as greengram, urease activity was significantly higher in sunflower residues incorporated plot. Before greengram, the urease activity was $31.27 \mu \mathrm{g} \mathrm{NH}^{+} \mathrm{g} \mathrm{soil}^{-1}$ $\mathrm{hr}^{-1}$.

Among the methods of establishment, there has been no significant difference in urease activity before different crops. But, numerically higher urease activity was observed in wet direct sowing before all the crops.

There was no significant difference in urease activity among the various sources of nutrient during 2016-17 before growing sunflower and rice. Before greengram, urease activity was highest in organic source of nutrient $(27.60 \mu \mathrm{g}$ $\mathrm{NH}^{+} \mathrm{g}$ soil $\left.{ }^{-1} \mathrm{hr}^{-1}\right)$. The interaction effect was found to be non significant.

The results of the analysis on $\mathrm{MBC}(\mu \mathrm{g} \mathrm{C} \mathrm{g}$ soil $^{-1}$ ) as influenced by sunflower residue incorporation, method of establishment and source of nutrient before growing various crops has been presented in Table 4. 
There was no significant difference in MBC in the bulk soil. Before growing rice as well as greengram, urease activity was significantly higher in sunflower residues incorporation plot. Before greengram, the maximum $\mathrm{MBC}$ was $187.09 \mu \mathrm{g} \mathrm{C} \mathrm{g} \mathrm{soil}{ }^{-1}$ in residues incorporation plot.

There has been no significant difference in MBC before different crops among the methods of establishment. But, numerically higher MBC was observed in transplanting before all the crops. There was no significant difference in MBC among the various sources of nutrient before growing sunflower and rice. Before greengram, MBC was highest in organic source of nutrient $\left(173.65 \mu \mathrm{g} \mathrm{C} \mathrm{g}\right.$ soil $^{-}$ $\left.{ }^{1}\right)$. The interaction effect was found to be non significant.

Dehydrogenase activity was significantly higher in sunflower residues incorporation. Before growing rice as well as greengram, phosphatase activity was significantly higher in the plot where sunflower residues were incorporated. So also urease as well as total microbial biomas carbon were higher in the plot where sunflower residue was incorporated.

This might be due to incorporation of crop residue acted as organic carbon source for higher growth of microbes leading higher activity of soil enzymes and higer value of total microbial biomass carbon. Jilani et al., (2007) revealed that the organic amendments hold great promise as a source of multiple nutrients and ability to improve soil characteristics.

Biochemical compounds resulting from the mineralization of organic residues or litter also render great impact on soil microorganisms. The incorporation of crop residues into the soil modifies its chemical and biochemical properties, including soil- enzyme activity, the behaviour of which has often been related to the amount as well as to the type of organic matter. Addition of tobacco and sunflower residues in soil increases the activities of most of the soil enzymes, while tomato residues increased only the amylase and phosphodiesterase activities (Perucci et al., 1984).

Dehydrogenase activity during decomposition of sunflower residues was higher in first week after that it declined (Kaur and Kapoor, 2000). There was no significant difference in microbial activity indicators with respect to methods of establishment.

Organic source of nutrient resulted in highest dehydrogenase activity before all the crops followed by $75 \% \mathrm{RDF}+25 \%$ organic and RDF. Similar trend was also observed for phosphatases activity, urease activity and total microbial biomas carbon. The findings are in conformity with findings of Verma et al., (2019).

The supply of additional mineralizable and readily hydrolysable $\mathrm{C}$ due to organic manure application results in higher microbial activity and higher microbial biomass carbon (Ingle et al., 2014). The enzyme activities in the soil are closely related to organic matter content and greater activities of dehydrogenase, in this treatment may also be due to enhanced microbial activity.

Application of balanced amount of nutrients and manure improve the microbial biomass carbon status of soil which corresponds to higher enzyme activity (Mandal et al., 2007). Organic matter can provide substantial nutrients for microorganism growth and reproduction. So rice straw incorporation in rice -wheat cropping system significantly increased $\mathrm{MBC}, \mathrm{MBN}$ and improved the urease, invertase, and catalase activities (Zhao et al., 2019). 
Table.1 Dehydrogenase activity as influenced by various treatments

\begin{tabular}{|c|c|c|c|}
\hline \multirow[t]{2}{*}{ Treatment } & \multicolumn{3}{|c|}{ Dehydrogenase activity ( $\mu \mathrm{g}$ TPF g soil $^{-1}$ day $^{-1}$ ) } \\
\hline & Sunflower & Sunflower & Sunflower \\
\hline \multicolumn{4}{|l|}{ Sunflower residue } \\
\hline Removal & 47.74 & 51.81 & 64.81 \\
\hline Incorporation & 47.36 & 56.58 & 72.08 \\
\hline Control & 47.68 & 48.81 & 50.83 \\
\hline S.Em. \pm & 0.32 & 0.21 & 0.23 \\
\hline $\operatorname{CD}(0.05)$ & NS & 0.71 & 0.79 \\
\hline \multicolumn{4}{|l|}{ Method of establishment } \\
\hline Dry direct sowing & 48.08 & 52.20 & 62.87 \\
\hline Wet direct sowing & 48.03 & 52.81 & 62.95 \\
\hline Transplanting & 46.68 & 52.26 & 61.91 \\
\hline S.Em. \pm & 0.19 & 0.16 & 0.27 \\
\hline $\mathrm{CD}(0.05)$ & NS & NS & NS \\
\hline \multicolumn{4}{|l|}{ Source of nutrient } \\
\hline Organic(100 \% N FYM) & 47.63 & 52.22 & 65.52 \\
\hline $75 \%$ RDN+25 \% N Organic & 47.72 & 52.67 & 61.81 \\
\hline RDF & 47.45 & 52.38 & 60.41 \\
\hline SEm \pm & 0.24 & 0.23 & 0.23 \\
\hline $\mathrm{CD}(0.05)$ & NS & NS & 0.64 \\
\hline
\end{tabular}

Table.2 Phosphatase activity as influenced by various treatments

\begin{tabular}{|c|c|c|c|}
\hline \multirow[t]{2}{*}{ Treatment } & \multicolumn{3}{|c|}{ Acid phosphatases activity ( $\mu \mathrm{mol}$ paranitrophenol g soil ${ }^{-1} \mathrm{hr}^{-1}$ ) } \\
\hline & Sunflower & Sunflower & Sunflower \\
\hline \multicolumn{4}{|l|}{ Sunflower residue } \\
\hline Removal & 0.99 & 1.23 & 1.61 \\
\hline Incorporation & 0.99 & 1.47 & 1.94 \\
\hline Control & 0.98 & 1.12 & 1.87 \\
\hline S.Em. \pm & 0.05 & 0.01 & 0.01 \\
\hline $\mathrm{CD}(\mathbf{0 . 0 5})$ & NS & 0.03 & 0.03 \\
\hline \multicolumn{4}{|c|}{ Method of establishment } \\
\hline Dry direct sowing & 1.01 & 1.25 & 1.77 \\
\hline Wet direct sowing & 0.99 & 1.26 & 1.83 \\
\hline Transplanting & 0.97 & 1.31 & 1.82 \\
\hline S.Em. \pm & 0.018 & 0.01 & 0.01 \\
\hline $\mathrm{CD}(0.05)$ & NS & NS & 0.03 \\
\hline \multicolumn{4}{|l|}{ Source of nutrient } \\
\hline $\begin{array}{l}\text { Organic(100 \% N } \\
\text { FYM) }\end{array}$ & 0.99 & 1.27 & 1.68 \\
\hline $\begin{array}{l}75 \% \text { RDN }+25 \% \mathrm{~N} \\
\text { Organic }\end{array}$ & 0.99 & 1.28 & 1.80 \\
\hline RDF & 0.99 & 1.28 & 1.94 \\
\hline SEm \pm & 0.012 & 0.01 & 0.01 \\
\hline $\mathrm{CD}(0.05)$ & NS & NS & 0.02 \\
\hline
\end{tabular}


Table.3 Urease activity as influenced by various treatments

\begin{tabular}{|c|c|c|c|}
\hline \multirow[t]{2}{*}{ Treatment } & \multicolumn{3}{|c|}{ Ureases activity $\left(\mu \mathrm{g} \mathrm{NH}{ }^{+}\right.$g soil $\left.^{-1} h^{-1}\right)$} \\
\hline & Sunflower & Sunflower & Sunflower \\
\hline \multicolumn{4}{|l|}{ Sunflower residue } \\
\hline Removal & 17.87 & 19.03 & 24.80 \\
\hline Incorporation & 17.90 & 22.10 & 31.27 \\
\hline Control & 17.64 & 17.48 & 21.81 \\
\hline S.Em. \pm & 0.27 & 0.06 & 0.08 \\
\hline $\mathrm{CD}(\mathbf{0 . 0 5})$ & NS & 0.24 & 0.29 \\
\hline \multicolumn{4}{|l|}{ Method of establishment } \\
\hline Dry direct sowing & 17.89 & 19.82 & 26.09 \\
\hline Wet direct sowing & 18.21 & 19.64 & 26.08 \\
\hline Transplanting & 17.31 & 19.15 & 25.75 \\
\hline S.Em. \pm & 0.32 & 0.13 & 0.19 \\
\hline $\mathrm{CD}(0.05)$ & NS & NS & NS \\
\hline \multicolumn{4}{|l|}{ Source of nutrient } \\
\hline Organic(100 \% N FYM) & 17.82 & 19.45 & 27.60 \\
\hline $75 \%$ RDN+25 \% N Organic & 17.90 & 19.71 & 25.87 \\
\hline RDF & 17.69 & 19.45 & 24.41 \\
\hline SEm \pm & 0.18 & 0.15 & 0.14 \\
\hline $\mathrm{CD}(0.05)$ & NS & NS & 0.40 \\
\hline
\end{tabular}

Table.4 Total MBC as influenced by various treatments

\begin{tabular}{|c|c|c|c|}
\hline \multirow[t]{2}{*}{ Treatment } & \multicolumn{3}{|c|}{ Total MBC $\left(\mu \mathrm{g} \mathrm{C} \mathrm{g} \mathrm{soil}{ }^{-1}\right)$} \\
\hline & Sunflower & Sunflower & Sunflower \\
\hline \multicolumn{4}{|l|}{ Sunflower residue } \\
\hline Removal & 141.16 & 156.77 & 171.94 \\
\hline Incorporation & 140.83 & 165.80 & 187.09 \\
\hline Control & 140.28 & 143.98 & 141.87 \\
\hline S.Em. \pm & 0.35 & 0.62 & 0.45 \\
\hline $\operatorname{CD}(0.05)$ & NS & 2.14 & 1.55 \\
\hline \multicolumn{4}{|c|}{ Method of establishment } \\
\hline Dry direct sowing & 138.42 & 154.64 & 166.29 \\
\hline Wet direct sowing & 140.04 & 155.54 & 166.21 \\
\hline Transplanting & 143.82 & 156.38 & 168.41 \\
\hline S.Em. \pm & 0.30 & 0.46 & 0.26 \\
\hline $\mathrm{CD}(0.05)$ & NS & NS & NS \\
\hline \multicolumn{4}{|l|}{ Source of nutrient } \\
\hline $\begin{array}{l}\text { Organic(100 \% N } \\
\text { FYM) }\end{array}$ & 140.13 & 155.77 & 173.65 \\
\hline $\begin{array}{l}75 \% \text { RDN+25 \% N } \\
\text { Organic }\end{array}$ & 142.11 & 155.60 & 165.17 \\
\hline RDF & 140.44 & 155.19 & 162.09 \\
\hline SEm \pm & 0.25 & 0.49 & 0.25 \\
\hline $\mathrm{CD}(0.05)$ & NS & NS & 0.70 \\
\hline
\end{tabular}


Among the residue management options of sunflower, dehydrogenase activity, phosphatase activity, urease activity and total microbial biomass carbon were higher in sunflower residue incorporation. There was no significant effect of method of establishment on microbial activity. Among source of nutrients higher microbial activity in terms of all enzyme activities and total microbial biomass carbon were observed with supply of nutrients through pure organic source.

\section{Acknowledgement}

The author acknowledges the support of Department of Science and Technology, Government of India, New Delhi, for granting INSPIRE fellowship for the Ph.D research work.

\section{References}

Casida LE, Klein DA and Santoro T. 1964. Soil dehydrogenase activity. Soil Science. 98: 371-376.

Evazi $Z$ and Tabatabai MA. 1979. Phosphatase in soil. Soil Biol. Biochemistry, 9 : 167-172.

Ingle SS, Jadhao SD, Kharche VK, Sonune BA and Mali DV. 2014. Soil biological properties as influenced by long-term manuring and fertilization under sorghum (Sorghum bicolor)-wheat (Triticum aestivum) sequence in Vertisols, Indian Journal of Agricultural Sciences, 84: 452-457

Inubishi $\mathrm{K}$, Brookes PC and Jenkinson DS. 1991. Soil microbial biomass carbon, nitrogen and ninhydrin- $\mathrm{N}$ in aerobic and anaerobic soils measured by fumigation, Soil Biology Biochemistry, 23: 737-741. Jackson ML. 1973. Soil Chemical Analysis. Prentice Hall of India Pvt. Ltd., New Delhi.

Joergensen RG. 1996. The fumigation- extraction method to estimate soil microbial biomass: Calibration of the $\mathrm{K}_{\mathrm{EC}}$ value, Soil Biology Biochemistry, 28: 25-31.

Kaur K and Kapoor KK. 2000. Carbon mineralization, microbial biomass and nutrient release pattern during decomposition of sunflower residues in soil, Applied Biological Research, 2 (1/2): 39-44.

Mandal A, Patra AK, Singh D, Swarup A, Masto RE. 2007. Effect of long-term application of manure and fertilizer on biological and biochemical activities in soil during crop development stages, Bioresource Technology, 98: 3585-3592.

Pancholy SK and Rice EL. 1973. Soil enzymes in relation to old field succession: amylase, invertase, cellulose, dehydrogenase and urease. Soil Sci. Soc. America Proc., 37: 47-50.

Perucci P, Scarponi L, and Businelli M. 1984. Enzyme activities in a clay-loam soil amended with various crop residues, Plant and Soil, 81 (3): 345-351.

Tanaka DL, Anderson RL and Rao SC.2005. Crop sequencing to improve use of precipitation and synergise crop growth, Agronomy Journal. 97(2):385-390.

Vance ED, Brookes PC and Jenkinson DS. 1987. An extraction method for measuring soil microbial carbon, Soil Biology Biochemistry, 19: 703-707.

Verma A, Sharma U, Tripathy D and Devi M. 2019. Effect of Organic Nutrient Sources on Biological Properties of Soil in Potato and Turmeric Cropping System, Int. J. Curr. Microbiol. App. Sci, 8(8): 1045-1052.

Zhao, Xinlin Zhao, Guoyin Yuan, Huoyan Wang, Dianjun Lu, Xiaoqin Chen and Jianmin Zhou. 2019. Effects of Full Straw Incorporation on Soil Fertility and Crop Yield in Rice-Wheat Rotation for Silty Clay Loamy Cropland, Agronomy, 133(9): 1-12. 


\section{How to cite this article:}

Tapas Ranjan Sahoo, R. K. Paikaray, K. N. Mishra and Rath, B. S. 2020. Microbial Activity as Influenced by Sunflower Residue Incorporation, Method of Establishment and Nutrient Management of Rice in Rice-Greengram Sunflower Cropping System in Odisha, India. Int.J.Curr.Microbiol.App.Sci. 9(04): 921-928. doi: https://doi.org/10.20546/ijcmas.2020.904.110 